\title{
Territorialidades fluidas: corsários franceses e tráfico negreiro no Rio da Prata (1796-1799). Tensôes locais-tensões globais ${ }^{1}$
}

\author{
Maria Verónica Secreto* \\ Universidade Federal Fluminense, Niterói - RJ, Brasil
}

\section{RESUMO}

Entre 1798 e 1799 dois corsários franceses, o capitão Carbonell e o capitão Le Bozec utilizaram o porto de Montevidéu como base para conduzir suas presas. O modus operandi destes, comandantes da corveta Le Grand Bonaparte e da fragata La Republicaine, respectivamente, foi o de espreitar suas presas perto do Rio de Janeiro, águas marítimas pelas quais navegavam inimigos da França: portugueses e ingleses. A presa era conduzida até o porto de Montevidéu para vender seu produto: os carregamentos e navios. As açôes dos capitães Carbonell e Le Bozec desnudam um conjunto de relações do espaço platino. As ações dos dois corsários evidenciam algumas das tensôes ao interior da classe comerciante, sobretudo, o conflito entre os comerciantes vinculados a Cádiz e os vinculados ao Brasil.

Palavras-chave: Rio da Prata; corsários; franceses; traficantes; escravos.

\section{ABSTRACT}

Between 1798 and 1799, two French privateers, Captain Carbonell and Captain Le Bozec, used the port of Montevideo as a base. The modus operandi of the commanders of, vessels Le Grand Bonaparte and La Republicaine, respectively, was to stalk their prey near Rio de Janeiro, maritime waters sailed by enemies of France: the Portuguese and the English. The prey was then conducted to the port of Montevideo for sale of ships and their cargo. The actions of the two captains lay bare a set of relationships in the La Plata River area, highlighting some of the tensions within the trading class, especially between Brazilian traders and those linked to Cádiz.

Keywords: La Plata River; privateers; French; slave trade; slaves.

DOI - http://dx.doi.org/10.1590/2237-101X017033005

Artigo recebido em 16 de julho de 2015 e aprovado para publicação em 8 de novembro de 2016.

${ }^{1}$ Agradeço a Alex Borucki que, num encontro casual no Archivo General de la Nación Argentina em abril de 2009, me chamou a atenção para este caso colocando-me em contato com parte da documentação. AGN, Divisão Colonia, Montevideo, 1799. Sala IX- 2-9-4. Agradeço a Jaime Rodrigues a leitura de uma versão preliminar, embora todos os problemas que possam subsistir sejam de minha inteira responsabilidade.

* Doutora em História Econômica pela Unicamp e professora associada do Departamento de História da UFF. E-mail: veronica.secreto@ig.com.br. 
Desde la cabina de comando, el piloto nos acordó, por los altoparlantes, en los tres idiomas habituales, castellano, inglés y francés, una gracia suplementaria. Harto tal vez de incitarnos a admirar, por reglamento, la consabida ciudad de Casablanca en el amanecer, el infaltable Cristo del Corcovado en los despegues de Rio y un Porto Alegre puramente nominal, nos informó que a nuestra derecha podiamos contemplar, si lo deseábamos, "el punto en que confluyen el rio Paraná y el rio Uruguay para formar el Rio de la Plata". [...] Visto desde la altura, ese paisaje era el más austero, el más pobre del mundo-Darwin mismo, a quien casi nada dejaba de interesar, ya habia escrito en 1832: "no hay ni grandeza ni belleza en esta inmensa extensión de agua barrosa”$Y$ sin embargo ese lugar chato y abandonado era para mí, mientras lo contemplaba, más mágico que Babilonia, más hirviente de hechos significativos que Roma o que Atenas, más colorido que Viena o Amsterdam, más ensangrentado que Tebas o Jericó. Era mi lugar: en él, muerte y delicia me eran inevitablemente propias.

Juan José Saer, El Río sin Orillas, Buenos Aires, Alianza, 1991

\section{Introdução}

No final do século XVIII o mar estava muito agitado, e não se trata de uma metáfora. Referimo-nos aos desdobramentos marítimos das guerras entre as potências coloniais. A Revolução Francesa e a posterior execução na guilhotina de Luiz XVI levaram as monarquias europeias a uma coalizão contra a França revolucionária. Essa coalisão durou de 1792 a 1797 e em seu momento de máxima expansão incluiu Áustria, Grã-Bretanha, Nápoles e Sicília, Sardenha e vários outros Estados italianos e os Reinos de Prússia, Espanha e Portugal. O resultado foi declaraçôes de guerra múltiplas, cruzadas entre as potências e reinos acima por um lado e a França por outro. Na conflagração bélica a Espanha teve vantagem inicial, conseguindo alguns êxitos militares no que se conhece na história da Espanha como Guerra del Rosellón, até que a França reverteu essa tendência atravessando os Pireneus e ocupando o 
norte do país ibérico. A partir desse momento Carlos IV se viu forçado a sair da coalizão e assinar a paz em Basileia em 1795.

Em 18 de agosto de 1796, França e Espanha assinaram um tratado, Segundo Tratado de San Idelfonso, de aliança ofensiva e defensiva que atrelava a Espanha aos interesses franceses. ${ }^{2}$ Em cláusula secreta o tratado estabelecia que em caso de guerra comum às duas partes contratantes, os navios de guerra e corsários franceses podiam armar-se, conseguir provisões, entrar, sair e conduzir suas presas para vender nos portos de Cuba, Trinidade, Porto Rico e San Agustín, enquanto os navios espanhóis podiam fazer o mesmo nos portos do Caribe francês. Uma Real Cédula precavia sobre a possibilidade da circulação de versões a respeito do tratado, ${ }^{3}$ evidenciando o temor espanhol de que a cláusula fosse divulgada, o que evidenciaria sua fraqueza.

A Revolução Francesa tinha inaugurado um período de clima de desconfiança entre Espanha e França. Nas Américas, desde o início da Revolução e, sobretudo, no período da guerra entre a França e a Espanha, se sucederam proibiçóes sobre a circulação de escritos "sediciosos" provenientes da França. Os imigrantes desse país estiveram na mira das autoridades coloniais, sempre suspeitos de tramar conspiraçóes contra a monarquia espanhola e de aguardarem reforços vindos da França. ${ }^{4}$ A paz de 1795 e o tratado de amizade de 1796 não modificaram muito o sentimento de desconfiança a respeito dos franceses nos territórios hispano-americanos, mas suavizou o tratamento recebido das autoridades. A aparição nos portos hispano-americanos dos navios de guerra e corsários franceses passou a ser uma rotina, mais ou menos aceita pela população e administração locais.

Como tinha se tornado rotina a chegada de navios negreiros. Um conjunto de medidas administrativas de cunho comercial do último quartel do século XVIII incentivou o tráfico negreiro no Rio da Prata. A população negra e escrava cresceu nesse período como nunca antes graças à chegada de novos contingentes de escravos africanos. Entre 1778 e 1810, salienta Alex Borucki, a população de Buenos Aires na margem sul do Rio da Prata cresceu

\footnotetext{
${ }^{2}$ Real Cédula de S. M. y Señores del Consejo en que se manda observar y guardar el tratado de Alianza ofensiva y defensiva ajustado entre su Real Persona y la República Francesa. 1796. Por Bartolomé Muńoz Torres, España, Imprenta Real, 1796.

${ }^{3}$ Real Cédula de S. M. y señores del Consejo, en que se prohíbe la venta de los Tratados de la Paz ajustada con la Francia, que no se hayan impreso en la Real Imprenta de Madrid, y también su reimpresión y la de qualesquiera otros papeles ú obras que se manden imprimir por S.M., á no preceder su soberano consentimiento. Segovia, Imprenta Espinosa, 1796.

${ }^{4}$ TORRES PUGA, Gabriel. Centinela Mexicano contra francmasones. Un enredo detectivesco del licenciado Boruda en las causas judiciales contra los franceses de 1794. EHN, n. 33, p. 57-94, jul./dez. 2005. SECRETO, Maria Verónica. Sediciosa Buenos Aires: o complot de escravos e franceses no Rio da Prata, 1795. Historia Unisinos, v. 17, p.146-157, 2013; SECRETO, Maria Verónica. Brindes, textos e livros proibidos: a conspiração de escravos e franceses na Buenos Aires colonial. Outros Tempos, v. 11, p. 188-207, 2014. ORTEGA, Exequiel Cesar, El complot colonial. Buenos Aires: Ayacucho, 1947. JOHNSON, Lyman. Los talleres de la Revolución. La Buenos Aires plebeya y el mundo del Atlántico, 1776-1810. Buenos Aires: Prometeo, 2013.
} 
$34 \%$ enquanto a escrava o fez 101\% e em Montevidéu, na margem norte do Rio da Prata, a população escrava cresceu $486 \%$ no mesmo período. 5

Esses dois eventos, o tráfico negreiro e corso francês, estavam chamados a conviver e a produzir uma série de cruzamentos originais nas conflitivas águas do Atlântico Sul.

\section{O corso como ação de guerra}

A participação dos corsários na área do Caribe é bastante conhecida; também é conhecido o papel dos corsários nas guerras da Independência hispano-americanas; mas pouco sabemos do rol deles nos mares do Sul, ainda durante o século XVIII, vinculado à crise do Antigo Regime, ao abolicionismo francês de 1794-1802 e às guerras napoleônicas. $\mathrm{O}$ corso francês pode ser dividido em três períodos: o da mesma revolução, que nas Antilhas teve a forma de guerra de corso; o do ciclo napoleônico e o das independências hispano-americanas. ${ }^{6}$ Nos interessa neste caso o fim do ciclo da revolução e o início do ciclo napoleônico e suas relaçóes com o tráfico de escravos e os interesses locais. Este recorte se deve à relação que se estabelece neste artigo entre corso e tráfico de escravos no contexto do primeiro abolicionismo francês (1794-1802), daqui que alguns casos muito interessantes da primeira década do século XIX não sejam abordados, como é o caso do corsário Hypolito Mordielle. ${ }^{7}$

O corso era uma empresa naval de um particular contra os inimigos de seu Estado, realizado com permissão e sob sua autoridade com o objetivo de causar perdas no comércio inimigo e atrapalhar o neutral que com eles se relacionasse. ${ }^{8}$ Como prática de guerra esteve muito estendido na história europeia e reconhecido por códigos e tratados. A primeira recopilação de costumes e leis marítimas dispersas no direito romano, grego, bizantino, italiano, francês e espanhol foi o Libre del Consolat de Mar (1320-1330) originário de Barcelona e que vigorou em todo o Mediterrâneo. Posteriormente, em 1681, durante o reinado de Luiz XIV, aparece a Ordennance de la Marine. Ambas regulamentavam o corso, tendo matérias específicas sobre presas e patentes de corso. O que diferenciava corso de pirataria era a licença ou patente emitida por um rei, príncipe ou estado soberano. E o que legitimava a presa era o fato de ser realizada contra inimigos do estado outorgante. Segundo Moreno Álvarez, a

\footnotetext{
${ }^{5} \mathrm{O}$ mesmo autor indica as seguintes concentraçóes nos desembarques de escravos no período 1777-1812: $1777-1791,15,7 \%$; 1792-1799, 19,3\%; 1800-1806, 45,6\% e 1807-1812, 19,4\%. Borucki, ALEX. The Slave Trade to the Río de la Plata, 1777-1812: Trans-Imperial Networks and Atlantic Warfare. Colonial Latin American Review, v. 20, n. 1, p, 88, abr. 2011.

${ }^{6}$ VIDALES, Carlos. Corsarios y piratas de la Revolución Francesa en las aguas de la emancipación hispanoamericana. L’Amérique Latine face a la Révolution Française. Caravelle, n. 54, p. 247-262, 1990.

${ }^{7}$ GRANDIN, Greg. O império da necessidade. Escravatura, liberdade e ilusáo no Novo Mundo. Rio de Janeiro: Rocco, 2014, p. 27-53.

${ }^{8}$ AZCARRAGA Y DE BUSTAMANTE, José Luis de. El corso marítimo, concepto, justificación e historia. Madri: Consejo Superior de investigaciones científicas, 1950.
} 
patente de corso tem sua raiz no chamado direito de represália de origem medieval pelo qual se alguém era atacado por barco inimigo podia atacar outros de súditos do mesmo príncipe até recuperar o monto perdido.?

Afirma Cruz Barney que, no caso do corso espanhol, as disposiçóes eram ditadas pelo monarca por meio de ordenanças adicionais: reais declaraçóes, reais ordens e reais cédulas. Ademais, o corso devia sujeitar-se às instruçôes recebidas no momento da concessão da patente, que era o documento específico que outorgava a autorização e especificava a validade e condiçốes do corso. As Ordenações da Marinha de 1681 que regiam o corso francês constituem um conjunto de disposiçôes com enorme influência no corso europeu em geral e no direito hispano-indiano em particular. Esta obra de Colbert é considerada um verdadeiro Corpus Iuris Maris. ${ }^{10}$ Em 1702, Espanha e França sancionaram de forma conjunta a Ordenança de Corso de 5 de agosto. A matéria da legislaçáo sobre corso é: patentes, portos permitidos, das presas e da legitimidade destas, dos tribunais que julgam a legitimidade das presas, dos armadores, das percentagens que correspondem à Fazenda Real, aos armadores, capitães e tripulação etc. Se durante todo o século XVIII há abundante legislação das duas naçóes sobre corso, essa legislação conjunta constitui um importante antecedente do Segundo Tratado de São Idelfonso sobre esta matéria.

As declarações de guerra, em geral, eram seguidas de um convite aos vassalos ou cidadáos para armar-se em corso. Vejamos dois exemplos. Em 1779 o rei da Espanha sancionou uma Real Cédula na que insertava a Real Ordenança de corso e declaraçóes convenientes para sua aplicação nas Índias. A mesma começava:

Como a segurança do comercio marítimo e navegação de meus vassalos exige que se faça um corso ativo e vigoroso contra os súditos do rei da Inglaterra nos mares da América, onde a vasta extensão de meus domínios os deixa mais expostos que em Europa ao insulto e depredação dos inimigos e proporciona menos asilos às naves mercantes que trafegam em seus portos e costas; tenho vindo oferecer a todos meus súditos americanos que armarem contra os ingleses a proteção, auxílios, franquias e prêmios contidos na Ordenança expedida o primeiro do presente mês de julho. ${ }^{11}$

\footnotetext{
${ }^{9}$ MORENO ÁLVAREZ, Leonardo Guillermo. La piratería americana y su incidencia en el Nuevo Reino de Granada, siglos XVI-XVIII: un ensayo bibliográfico. Fronteras de la Historia, n. 12, p. 373-404, 2007.

${ }^{10}$ CRUZ BARNEY, Oscar. El corso marítimo, México: UNAM, 2013, p. 82.

${ }^{11}$ Como la seguridad del comercio marítimo y navegación de mis vasallos exige que se haga un corso activo y vigoroso contra los súbditos del Rey de Inglaterra en los mares de América donde la vasta extensión de mis dominios los deja más expuestos que en Europa al insulto y depredación de los enemigos, y proporciona menos asilos a las naves mercantes que trafican en sus puertos y costas; he venido en dispensar a todos mis súbditos americanos que armaren contra los ingleses la protección, auxilios, franquicias y premios contendida en la Ordenanza expedida el primero del presente mes de julio. Real Cédula de S. M. en que se inserta la Real Ordenanza de Corso con las declaraciones convenientes para su observancia en los dominios de Indias. 1ํ de julio de 1779. In: CRUZ BARNEY, Oscar. El Corso Marítimo, op. cit., p. 410. Tradução do autor.
} 


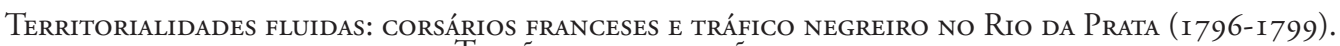

Enquanto a Convenção Nacional Francesa, em final de janeiro de 1793, decretava que os cidadãos franceses podiam armar-se em corso contra os ingleses para o qual o ministro de Marinha expediria as "lettres de marque" conforme o seguinte modelo:

Liberdade e igualdade

Em nome da República francesa, o Conselho Executivo da República Francesa permite, pela presente a ...... de armar e equipar em guerra um .... nomeado .... do porto de ... de ... toneladas aproximadamente, atualmente no porto de ... com um tal número de canhóes, balas de canhão, e tal quantidade de pólvora, chumbo e outras muniçóes e disposições que considere necessárias para capacitá-lo para a corrida contra os piratas, ladróes, vagabundos, e genericamente, todos os inimigos da República Francesa.

O presente serve para ... meses, a contar da data do seu registo". ${ }^{12}$

Essas declarações, com conteúdo fortemente político, se ajustavam do ponto de vista judicial e do direito internacional ao corpus legal sobre o corso e as presas de guerra e implicavam a mobilização de recursos humanos e econômicos de considerável envergadura. Assim, nos informa Gallois que depois do tratamento na Convenção Nacional Francesa sobre o tema do corso, se formou uma sociedade por açôes com um capital de 20 milhóes de francos denominada Armateurs de la Liberté, contava com dois navios de 74 canhóes, seis fragatas de 40; seis fragatas de 36, vinte de 24 e cinco de 18 canhóes. ${ }^{13}$ No Rio da Prata foi conhecido o expediente do corso em período de guerra, inclusive armando barcos mercantes para esse fim. Em 1735-1737, quando foi realizado o sítio de Colônia de Sacramento, o governador de Buenos Aires, Vértiz y Salcedo, ordenou ao proprietário dos navios de registro, Francisco de Alzaybar, que os armasse em corso, pedido ao qual não se podia negar porque a licença de comércio concedida a ele o convertia em "capitão de mar e de guerra" . ${ }^{14}$ Posteriormente, em 1800, o próprio consulado de comércio de Buenos Aires determinou a necessidade de armar corsários com finalidades "defensivas”, não sem antes insistir em que os barcos da Armada Real que estavam da base naval de Montevidéu saíssem quando se apresentava alguma ameaça, sobretudo de corsários ou baleeiros ingleses. Ante a imobilida-

\footnotetext{
12 "Liberté et égalité. Au nom de la République française, le Conseil Exécutif de la République française permet, par ces présentes, à ..... de faire armer et équiper en guerre un .... nommé le.... du port de ... de .... Tonnage ou environ, actuellement au port de .... avec un tel nombre de canons, boulets, et telle quantité de poudre, plomb et autres munitions de guerre et vivres qu'il jugera nécessaire pour le mettre en état de courir sur les pirates, les forbans, gens sans aveu, et généralement tous les ennemis de la République française. Le présent servir que pour ... mois seulement, compter de la date de leur registrèrent." GALLOIS, Napoleon. Corsaires françaises sous la République et l'empire. Le Mans: Julien Lanier et Co. Libraires — Editeurs/Paris: Ledoyen Galerie D’Orleans, 1847, p. 13-14. Tradução do autor.

${ }^{13}$ Ibidem, p. 23.

${ }^{14}$ JUMAR, Fernando. Colonia de Sacramento y el complejo portuario rio-platense 1716-1778. In: SILVA, Hernan (Dir.). Los caminos del Mercosur: Historia económica regional. Etapa Colonial. México: Instituto Panamericano de Geografia e Historia, 2004, p. 177-178.
} 
de dos barcos da armada, o consulado comprou e armou um bergantim batizado Francisco Xavier, o Buenos Aires, e uma escuna, Carolina. ${ }^{15}$

A historiografia sobre piratas e corsários nas Américas se refere, predominantemente, à área que foi a mais "castigada" ou "protegida" pela presença destes: Caribe, América Central e a costa do México. Mas vejamos como o corso atingiu uma região que passou a ter centralidade para o império espanhol a partir do último quartel do século XVIII.

\section{O corso nas Guerras Navais e as açóes de Le Grand Bonaparte e La Republicaine}

Nas chamadas Guerras Navais (de 1796 a 1808, como o interregno de paz: 1802-1804) a Espanha seguiu três estratégias para manter o comércio entre a América e a metrópole: abriu os portos ao comércio com navios neutrais; estabeleceu as permissóes de carregamento conhecidas como "doble registro de simulação" outorgado por autoridades espanholas a capitães de barcos neutrais; e outorgou patentes de corso a franceses no Caribe Hispano. ${ }^{16}$ Embora essas três estratégias definam uma política geral para esquivar o obstáculo da presença da Armada e de corsários ingleses no Atlântico, houve uma série de outras que foram definidas no "improviso" ou ao calor das circunstâncias particulares.

Entre 1798 e 1799 dois corsários franceses, o capitão Carbonell e o capitâo Le Bozec, utilizaram o porto de Sáo Felipe e Santiago de Montevidéu como base para conduzir suas presas. O modus operandi destes, comandantes da corveta Le Grand Bonaparte e da fragata La Republicaine, respectivamente, foi espreitar suas presas perto do Rio de Janeiro, águas marítimas pelas quais navegavam inimigos da França: portugueses e ingleses. Uma vez realizada a captura, as presas eram conduzidas até o porto de Montevidéu para vender seu produto: os carregamentos e os navios. Montevidéu era o porto mais próximo que parecia cumprir os requisitos legais do corso e do Segundo Tratado de San Ildefonso.

Em 1799 a corveta Le Grand Bonaparte, ${ }^{17}$ comandada por Carbonell, apresou perto de Cabo Frio (Brasil) uma corveta inglesa, a Duff, pertencente à London Missionary Society, que transportava missionários, colonos, alguns engenheiros e ferramentas para formar uma colônia e missionar nas ilhas Marquesas, no Pacífico Sul, equidistantes entre a Papua Nova Guiné e o Peru. ${ }^{18}$ Depois desta apreensão Carbonell decidiu enviar a Duff para Montevidéu,

\footnotetext{
${ }^{15}$ Consulado de Buenos Aires, 1800-1807, sala IX- 4-8-2, AGN. NAVARRO FLORIA, Pedro. El consulado de Buenos Aires, 1790-1806. Tese (doutorado) - Universidad Complutense. Madri, 1992, p. 148-152.

${ }^{16}$ RODRIGUEZ TREVIÑO, Julio César. La red del corsario francés Juan Chevalier y sus presas angloamericanas en el Caribe durante las guerras navales (1796-1808). Revista América Latina en la Historia Económica, Instituto Mora, México, ano 22, n. 1, p. 115-149, jan./abr. 2015, p. 116. Também Lauren Benton salienta como essas estrategias foram importantes na primeira década do século XIX. BENTON, Lauren. Una soberanía extraña: la provincia Oriental en el Mundo Atlântico. 20/10 Historia. México: GM Ediciones, 2012.

${ }^{17}$ Optamos pela tradução dos nomes dos navios como aparece na documentação da administração espanhola.

${ }^{18}$ Virrey de Buenos Aires sobre salida de una presa inglesa. 1797. Estado, Buenos Aires, 80, n. 69, Archivo
} 


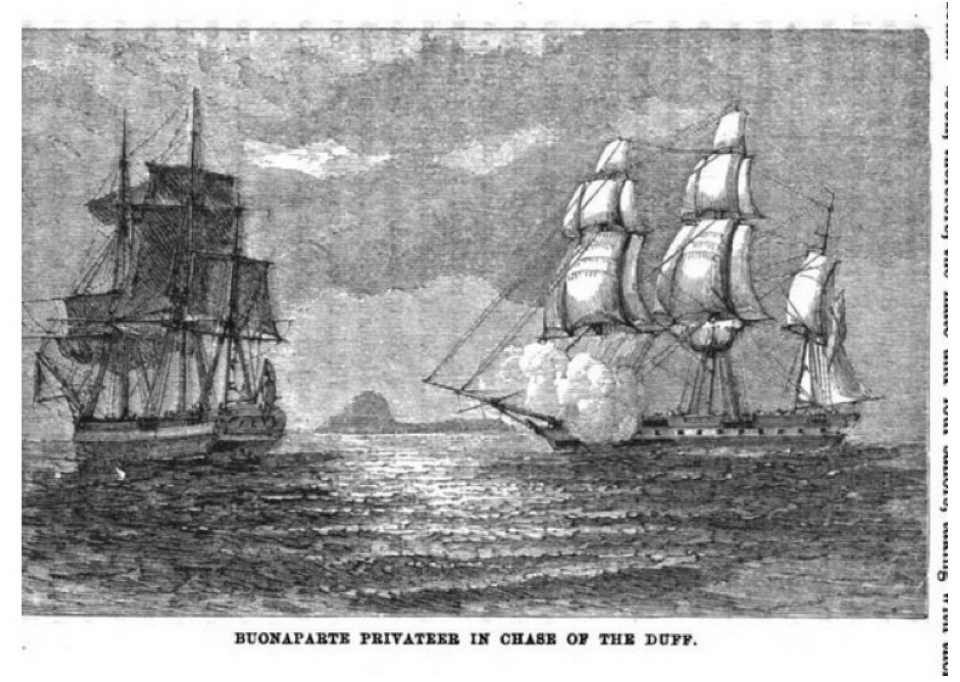

Fonte: William Gregory, 1800. JCB Archive of Early American Images.

Esta litografia denuncia o momento em que a Duffé perseguida pela corveta corsária Le Grand Bonaparte. Observe-se o Páo de Açúcar ao fundo, visto de dentro da Baía de Guanabara. Local quase impossível para uma captura corsária, mas evidencia que a mesma foi realizada perto do Rio de Janeiro.

comandada por um de seus oficiais, e ficar perto do Rio de Janeiro aguardando a oportunidade de realizar nova presa. Nos dias seguintes capturou uma zumaca, (embarcação muito parecida com um bergantim) de bandeira portuguesa, $A$ Nazaré, com carregamento de sal, ${ }^{19}$ e $O$ Postilhão da América, um bergantim correio português. Todos ingressaram no porto de Montevidéu e, salvo a Duff, foram vendidos com certa celeridade. A fragata Duff, da London Missionary Society, ficou no porto de Montevidéu depois que os corsários partiram, apesar das ordens para não abandonarem presa no porto.

Em 1798, a fragata francesa La Republicaine apressou em corso na costa da África três fragatas inglesas e, posteriormente, no mesmo local que a embarcação anterior, nas proximidades de Cabo Frio, a corveta portuguesa Rainha dos Anjos, que transportava escravos para o Rio de Janeiro. Na mesma expedição encontrou um comboio português escoltado por navios de guerra procedente de Lisboa, do qual apresou um bergantim. Como dizem Florentino, Ribeiro e Silva, o risco era intrínseco ao comércio negreiro. Eles mesmos salientam que

General de Indias. Ver: GREGORY, William. Manifestación visible de la divina providencia. Diario de um misionero cautivo 1798-1799. Estudio preliminar de José Maria Mariluz Urquijo. Buenos Aires: Congreso de la Nación/Academia Nacional de la Historia, 1996.

${ }^{19}$ Apesar de esta informação do expediente, Studer registra esta nave como sendo de bandeira portuguesa e propriedade do comerciante cataláo, residente em Montevidéu, Mila de la Roca. Foi apresada em Cabo Frio proveniente de Moçambique onde tinha carregado 250 escravos, dos que chegaram 156 a Montevidéu. Carbonell devolveu este bergantim e carga a seu dono, recebendo gratificação. STUDER, Elena S. F. de. La trata de negros en el Río de la Plata durante el siglo XVIII. Buenos Aires: Ed. da UBA, 1958. Anexo, gráfico: Buques negreros llegados al Río de la Plata desde 1742 hasta 1806. 
os navios baianos sofriam fugas, roubos e ataques de piratas, corsários. Como os casos do São João Nepomuceno, São Francisco de Paula e Nossa Senhora da Graça, que em 1797 foram saqueados por duas naus francesas e duas chalupas de bandeira inglesa na costa de Ajudá. ${ }^{20}$

A quantidade de presas realizadas por Carbonell e por Le Bozec demonstra a capacidade de "marinar" que eles tinham, isto é, de dotar os navios de tripulação suficiente para conduzir ao porto desejado. Um exemplo clássico em contrário é o da armada inglesa que, após a batalha de Trafalgar, abandonou muitos dos navios derrotados por não ter homens suficientes para tripulá-os. Le Bozec tripulou as três fragatas inglesas na costa da África e as mandou para Montevidéu ao mesmo tempo que se dirigia para a costa brasileira. Isto significa que ao momento de apresar a Rainha dos Anjos, ele já tinha destinado tripulação para três fragatas, sendo a zumaca carregada de escravos o quarto navio a ser provido de homens para ser conduzido a Montevidéu. O capitão francês Pierre Marie Le Bozec fez, no período entre 1796 e 1799, 76 apreensóes em corso. ${ }^{21} \mathrm{O}$ ano de 1799 marca o fim das aventuras de La Republicaine, que acabou sendo afundada por um navio inglês.

Apesar das resistências e da demora nas autorizaçóes para as vendas das presas, estas foram sendo realizadas. Dom Gerónimo Olloniego, comerciante local, comprou uma das fragatas inglesas com o intuito de destiná-la ao tráfico de escravos. Se por um lado a presença dos corsários franceses dificultando o comércio com o Brasil e interferindo no abastecimento de escravos produzia uma série de desconfianças e resistências, por outro, facilitava a aquisição dos navios para os comerciantes locais interessados na trata de escravos. Algumas medidas da coroa favoreciam e incentivavam a trata. A Real Cédula de 13 de abril de 1790 permitia aos vassalos espanhóis a compra de buques de construção estrangeira e a livre navegação com eles, ficando livres do direito de estrangeria e de alcabala se utilizados no comércio de escravos. Foi citando esses benefícios que Gerónimo Olloniego fez sua compra. O próprio Angel Izquierdo, Administrador de la Real Aduana, tinha manifestado que como as embarcaçôes apresadas eram iguais às que a recente legislação permitia adquirir pelos nacionais para o aumento da marinha mercante, recomendava a venda das três fragatas inglesas e da zumaca portuguesa. ${ }^{22}$

Começa a ser evidente que a presença dos corsários franceses e suas presas abriam possibilidades para alguns e dificultava os negócios de outros.

\footnotetext{
${ }^{20}$ FLORENTINO, Manolo; RIBEIRO, Alexandre Vieira; SILVA, Daniel Domingues da. Aspectos comparativos do tráfico de africanos para o Brasil (séculos XVIII e XIX). Afro-Ásia, n. 31, p. 104, 2004.

${ }^{21}$ ROUVIER, Charles. Histoire des marins français sous la République (de 1789 a 1803). Paris: Arthur Bertrand Éditeur, 1868.

${ }^{22}$ Arribo a Montevideo de Fragatas corsarias. 1799. Estado, Buenos Aires, 84, n. 1, Archivo General de Indias. Jerry W. COONEY afirma que, apesar de haver uma grande incidência de compra de navios norte-americanos e portugueses, não havia um patrão para a realização dessas compras e o que predominou foi o aproveitamento de oportunidades. COONEY, Jerry W. Neutral Vessels and Platine Slavers: Building a Viceregal Merchant Marine. Journal of Latin American Studies. v. 18, n. 1, p. 29, 1986.
} 


\section{O comércio com neutrais: Portugal}

Apesar de em sua primeira arribada Le Bozec ter conseguido vender com bastante facilidade a presa que levou até o Rio da Prata, o que deve tê-lo encorajado a voltar logo, na segunda se interpuseram alguns empecilhos. $\mathrm{O}$ vice-rei solicitou ao administrador da alfândega informaçóes sobre o ocorrido para poder realizar uma norma para todos esses casos. $\mathrm{O}$ administrador remeteu um conjunto de documentos, as licenças emitidas e um ofício em que colocava dúvidas sobre a legitimidade das patentes dos capitães Le Bozec e Carbonell e salientava os inconvenientes que ocasionaria no comércio com o Brasil se se dava entrada aos corsários franceses para a venda de suas presas nos portos do Prata. A isto o governador de Montevidéu acrescentou seu parecer. Para ele a licença para os franceses violava o artigo 22 do tratado preliminar de limites assinado entre Espanha e Portugal em 1777 no qual se estabelecia que:

E Sua Magestade Fidelissima em correspondencia desta restituição promette que em tempo algum, seja de paz, ou de guerra, em que a Coroa de Portugal não tenha parte, como se espera, e deseja, não consentirá que alguma Esquadra, ou Embarcaçáo de guerra, ou de Commercio Estrangeiras, entrem no dito Porto de Santa Catharina, ou nos da sua Costa immediata, nem que nelles se abriguem, ou detenháo, pecialmente sendo Embarcaçóes de Potencia, que se ache em guerra com a Coroa de Hespanha, ou que possa haver alguma suspeita de serem destinadas a fazer o Contrabando. Suas Magestades Fidelissima, e Catholica farão promptamente expedir as Ordens convenientes para a execução, e pontual observancia de quanto se estipula neste Artigo, e se trocará mutuamente hum duplicado dellas, a fim de que não fique a menor dúvida sobre o exacto cumprimento dos objectos, que inclue. ${ }^{23}$ (Grifo nosso)

Havia grande interesse em manter as vias do comércio legal (e embora não seja, nem pudesse ser dito, também o ilegal) com o Brasil. ${ }^{24}$ Nas últimas décadas do século XVIII, algumas medidas sobre o comércio das Índias incentivaram esse e acentuaram a preferência de longa data pelos luso-brasileiros.

O comércio do império espanhol em geral e o platino em particular se beneficiavam de um conjunto de leis e normativas. Em 1778 se sancionou o Regulamento de Livre Comércio, que consagrava a política de abertura mercantil iniciada em $1765 .{ }^{25} \mathrm{Em} 28$ de fevereiro de 1789 uma Real Cédula autorizava a introdução de escravos nas possessôes do Caribe espa-

\footnotetext{
${ }^{23}$ Espanha, Tratado preliminar de paz e limites na América Meridional relativo aos estados que nella possuem as coroas de Portugal e de Hespanha. Lisboa, Regia Oficina Typográfica, 1777.

${ }^{24}$ SILVA, Hernán Asdrúbal. "Bases para el establecimiento de vínculos comerciales entre el Río de la Plata y el Brasil a fines de la etapa colonial”, Anuario de Estudios Americanos. Tomo LIV, 2, p. 475-488, 1997.

${ }^{25}$ SILVA, Hernán. El comércio entre Espańa y el Rio da la Plata (1778-1810). Madrid: Banco de Espańa, 1993 , p. 16 e ss.
} 
nhol. Em 24 de novembro de 1791 reformula-se a Real Cédula sobre o livre comércio de escravos, incluindo nos direitos aos vice-reinos de Santa Fé e Buenos Aires a capitania de Caracas e as ilhas de Santo Domingo, Cuba e Porto Rico. A partir de 1795 o intercâmbio com o Brasil recebeu o estímulo da Real Ordem de 4 de março, que permitiu ao Rio da Prata comerciar com colônias estrangeiras. Disse Marcela Tejerina que esta medida teve por objeto dar saída aos produtos coloniais que não tinham colocaçáo na península, retornando com frutos (arroz, açúcar, aguardente), dinheiro e escravos. Apesar de este comércio dever realizar-se em navios nacionais, foram usados navios de "dupla bandeira" e inventadas vendas para esconder o verdadeiro proprietário do navio, muitas vezes luso-brasileiros. ${ }^{26} \mathrm{~A}$ partir $\mathrm{da}$ Real Ordem de 18 de novembro de 1797, que autorizou o comércio com neutrais, esse fluxo intensificou-se. Salienta Cooney que para fins de exportação os comerciantes do vice-reino enfrentavam dois sérios problemas que de alguma forma solucionaram-se com a Real Ordem de 1797, a guerra naval no Atlântico Norte que afetava a comunicação com o Atlântico Sul, e a pequena frota mercante própria. ${ }^{27}$ A revogação da Ordem de 18 de novembro de 1797 levou um grupo de comerciantes a solicitar em 1799, ante o Consulado de Comércio, autorização para remeter os frutos do país (cacau embarcados em Lima e Guayaquil) ao Brasil, para dali transportá-los no comboio português para Lisboa e desta aos portos espanhóis. ${ }^{28}$

$\mathrm{Na}$ documentação "polifônica" é possível perceber as tensôes que percorrem o Rio da Prata no final do século XVIII. Por uma parte um ano antes, em 1797 o vice-rei dava conta em sua correspondência da impossibilidade ou inviabilidade do envio de navios do Rio da Prata para a Espanha. A saída da fragata correio El Aguila foi feita com muita demora e depois de tomar muitas precauçóes porque na embocadura do rio tinha sido avistada uma fragata inglesa. ${ }^{29}$ Por sua vez a armada inglesa tinha bloqueado o porto de Cádiz. Salienta Rodriguez Trevińo: "Em Buenos Aires ficaram presos 33 navios, já não queriam organizar comboios apesar de ter acesso a duas fragatas e um saveiro de guerra, isso porque alguns navios inimigos tinham sido vistos na foz do rio". ${ }^{30}$ Mas também porque o rei tinha enviado ordens para que os caudais e frutos chegados do Callao fossem custodiados em terra, já que

\footnotetext{
${ }^{26}$ TEJERINA, Marcela. Luso-brasileños en el Buenos Aires virreinal: trabajo, negocios e intereses en la plaza naviera y comercial. Bahia Blanca: EdiUNS, 2004, p. 107-108.

${ }^{27}$ COONEY, Jerry W. Oceanic Commerce and Platine Merchants, 1796-1806: The Challenge of War. The Americas. v. 45, n. 4, p. 510-511, abr. 1989.

${ }^{28}$ Expediente sobre remitir los frutos del país al Brasil para transbordarlos al comboy portugués y dirigirlos a Lisboa con destino a los puertos de la metropolis. Consulado de Buenos Aires, 1771-1793, AGN.

${ }^{29}$ Virrey Interino de Buenos Aires sobre envío de navíos. 1797. Estado, Buenos Aires, 81, n. 13, Archivo General de Indias. Silva salienta que inclusive se chegou a utilizar navios corsários como navios correio. SILVA, Hernan. El corso rioplatense de fines del XVIII y principios del XIX. Una actividad sui generis XVII Coloquio de historia canario-americana. Las Palmas de Gran Canaria: Cabildo de Gran Canaria, 2006, p. 1592. 30 "En Buenos Aires estaban atrapados 33 buques, pues ya no querían organizar convoyes a pesar de tener a su disposición dos fragatas y una corbeta de guerra, lo anterior porque algunos barcos enemigos habían sido vistos en la boca del río." RODRIGUEZ TREVIÑO. Julio César. La red del corsario francés Juan Chevalier y sus presas angloamericanas en el Caribe durante las guerras navales (1796-1808), op. cit.
} 
não era possível ingressar na península. ${ }^{31}$ Confundidos com oficiais da marinha francesa, os corsários franceses podem ter ocasionado uma primeira boa impressão. La Republicaine e Le Grand Bonaparte podiam constituir-se em aliados interessantes na medida em que mantivessem os ingleses afastados, permitindo o comércio, senão com Cádiz, com os outros portos.

No ano de 1797 a tripulação de uma fragata que naufragou em Ponta Negra trazia notícias da Bahia de Todos os Santos, onde tinha estado. Lá, os tripulantes receberam informação de que uma esquadra inglesa-portuguesa se preparava para dirigir-se ao Rio da Prata, embora não houvesse declaração de guerra entre Espanha e Portugal. ${ }^{32}$ Enquanto o governador de Montevidéu denunciou que os corsários ingleses recebiam socorros no Brasil, o vice-rei do Rio da Prata avisou em 1799 aos mercadores do Rio de Janeiro sobre a presença dos corsários na região, porque as açóes destes interferiam nas redes comerciais entre o Rio da Prata e o Brasil. ${ }^{33}$ Esta ambiguidade caracteriza a situação. Vistos de fora os agentes oscilavam entre a cumplicidade e a desconfiança com os portugueses.

A escolha realizada por Le Bozec e Carbonell do Rio da Prata para conduzir as presas parece responder a uma favorável circunstância para o corso: a quase desproteção do Rio da Prata, a presença de barcos ingleses e portugueses na região e a ausência de concorrência de outros corsários. Ainda deve ter pesado na escolha o fato de que a região era objeto de intenso tráfico negreiro realizado por portugueses e ingleses. As reaçóes das autoridades no porto de Montevidéu e em Buenos Aires demonstram que a escolha foi num primeiro momento bem-sucedida. A "polifonia" de que falamos radica na multiplicidade de interesses que emergem da documentação, que evidencia diferentes posiçóes e diversos atores e interesses: a favor do corso, contra o corso, a favor do comércio com os portugueses, contra este, contra a intervenção do corso francês no tráfico negreiro etc. Alguns desses interesses aparecem representados nas vozes de administradores, armadores, corsários, comerciantes, traficantes, fiscais, advogados etc.

As posições mencionadas acima também mudaram com o tempo. Assim, em um primeiro momento, isto é, na primeira arribada dos corsários franceses em 1798, a presença deles constituía-se uma intimidação para os navios ingleses que rondavam a região, e, portanto, oferecia uma maior segurança para os navios espanhóis; pelo menos até que se evidencia tratar-se de corsários. Posteriormente, a presença deles e a espreita na costa brasileira foi percebida - ao menos pelos que defendiam essa via comercial — como uma ameaça à manutenção de um intercâmbio importante para o comércio rio-platense.

\footnotetext{
${ }^{31}$ Virrey Interino de Buenos Aires sobre envío de navíos. 1797. Estado, Buenos Aires, 81, n. 13, Archivo General de Indias.

${ }^{32}$ Sobre preparativos sospechosos de portugueses e ingleses. 1797. Estado, Buenos Aires, 81, n. 14. Archivo General de Indias.

${ }^{33}$ Sobre estas redes ver: TEJERINA, Marcela. Luso-brasileños en el Buenos Aires virreinal: trabajo, negocios e intereses en la plaza naviera y comercial, op. cit. PRADO, Fabrício Prado. A carreira transimperial de don Manuel Cipriano de Melo no rio da Prata do século XVIII. Topoi, v. 13, n. 25, p.168-184, 2012.
} 
Em nota reservada o administrador de la Real Aduana de Buenos Aires, Angel Izquierdo, informou ao vice-rei seu parecer sobre o que estava acontecendo. Em primeiro lugar comentou as notícias que tinham chegado de Paris. Lá o Diretório, motivado pelos excessos cometidos por alguns corsários, tinha decidido não conceder mais licenças para o corso nas colônias americanas, salvo as que fossem dadas pelo mesmo Diretório. As outras já outorgadas ficariam sem validade depois de trinta dias de sancionada a norma. Isto colocava em dúvida a validade das licenças ou patentes dos corsários Le Bozec e Carbonell. Por outra parte, Izquierdo salientava que o corso francês na costa brasileira destruía o comércio do Brasil, que tinha notável participação do platino. ${ }^{34}$

Os excessos a que se referia o Diretório talvez fossem os mesmos que denunciavam as autoridades coloniais de Caracas. ${ }^{35}$ As atividades de dois corsários, Mr. Roland e Mr. Dupin, assolando a área de Curaçao e abordando neutrais e espanhóis fizeram com que o funcionário elevasse suas queixas ao rei. Também o capitão Carbonell foi denunciado por cometer excessos com espanhóis e neutrais, ${ }^{36} \mathrm{e}$ Chevallier, que atuou no Caribe mexicano, foi acusado pelo mesmo motivo de pirataria. De qualquer forma as novas medidas do Diretório se referiam às patentes outorgadas no mesmo Caribe americano, que náo era o caso dos corsários Le Bozec e Carbonell.

Nesse contexto de abuso e de entorpecimento do comércio "regular", torna-se compreensível que as autoridades espanholas envolvidas na tramitação de autorização para a venda no porto de Montevidéu buscassem argumentos legais que permitissem barrar a ação dos corsários. Também o capitão português d. José Santana aproveitou o clima de contestação ao corso francês para reclamar sua embarcação e carga. Alegava que Le Bozec tinha utilizado bandeira inglesa na operação na qual a Rainha dos Anjos foi capturada. E manteve essa bandeira até ter assegurada a presa. ${ }^{37}$ Prática bastante habitual entre os corsários, mas de clara ilegitimidade, já que uma embarcação de bandeira inglesa seria claramente aliada da portuguesa, o que levou ao capitão Santana a ficar numa posiçáo vulnerável, permitindo que La Republicaine se aproximasse. Argumentava também que para a data em que seu navio foi rendido as patentes de Pierre Marie Le Bozec estariam vencidas.

A troca de bandeira não era o único tipo de prática ilegítima. Havia outras, como o duplo registro simulado que, embora guardando as formas da "legalidade", burlava a ver-

\footnotetext{
${ }^{34}$ Arribo a Montevideo de Fragatas corsárias. 1798-1806. Estado, Buenos Aires, 84, n. 1, Archivo General de Indias. As patentes que o Diretório tinha suspendido eram as que eram emitidas no Caribe. Ver também: TEJERINA, Marcela. Luso-brasileños en el Buenos Aires virreinal: trabajo, negocios e intereses en la plaza naviera y comercial, op. cit.

${ }^{35}$ Capitán General de Caracas sobre corsarios franceses, 1799. Estado, Caracas, 67, n. 56 (1), Archivo General de Indias.

${ }^{36}$ Excesos cometidos por la corbeta El Gran Bonaparte, 1798. Estado, Buenos Aires, 80, n. 59, Archivo General de Indias.

${ }^{37}$ VIDALES, Carlos, Corsarios y piratas de la Revolución Francesa en las aguas de la emancipación hispanoamericana, op. cit.
} 
dadeira identidade de navios e cargas. Neste sistema eram levados dois registros de carga a bordo, um simulado, isto é, falso, escrito na língua do suposto "proprietário" da mercadoria e do porto estrangeiro a que estavam destinadas, e outro registro, o autêntico, escrito em castelhano e indicando que as mercadorias iriam a um porto do império espanhol. Desta forma, se o barco era abordado por inimigos, seria apresentado o registro simulado, e quando abordado por aliados, o autêntico. ${ }^{38}$ Parece ser o caso do armador Manuel Aguirre, que se pronunciou no pleito sobre os corsários. Ele tinha comprado o navio Nuestra Señora de los Dolores para o comércio com o Brasil, o qual espanholizou, mas manteve seu capitão português para evitar os corsários ingleses. Mas Nossa Senhora/Nuestra Señora foi capturada por La Republicaine perto de Cabo Frio, em seu interior Le Bozec encontrou as patentes portuguesas e considerou legítima sua presa. Desta forma voltou para o porto de Montevidéu, do qual tinha saído, como presa de corso. Também parece ser o caso de O Nazareno/La Nazaret, registrado por Studer e mencionado acima. ${ }^{39}$

O fiscal em matéria criminal solicitou em 30 de janeiro de 1799 que se averiguasse se Le Bozec tinha por livres ou escravos a presa de Nossa Senhora dos Anjos e se pensava deixá-la ou levá-la. O governador deu ordens para que não fossem vendidos os navios nem a mercadoria, incluindo, nesta última, os escravos.

\section{Tomás Antonio Romero: juiz e parte}

De todas as peças que compóem o expediente em análise, chama-nos a atenção a iniciativa promovida pelo Defensor de Pobres de Buenos Aires. Ele começa transcrevendo integralmente a Real Cédula sobre Educação, Trato e Ocupação dos Escravos de $1789,{ }^{40}$ Real Cédula que tem gerado alguns debates. ${ }^{41}$ Conhecida como uma norma que gerou grande resistência entre os proprietários de escravos de Santo Domingo e de outras possessóes espanholas e que por esse motivo náo foi aplicada ou teve pouco "acatamento", ela se caracteriza por zelar pelo bom trato dos escravos e por impor a mediação do Estado na relaçấo entre o senhor e o escravo, uma vez que define "direitos e garantias". Depois desta transcrição, o Defensor

\footnotetext{
${ }^{38}$ RODRIGUEZ TREVIÑO, Julio César. La red del corsario francés Juan Chevalier y sus presas angloamericanas en el Caribe durante las guerras navales (1796-1808), op. cit.

${ }^{39}$ Studer registra este barco nave como sendo de bandeira portuguesa e propriedade do traficante vizinho de Montevidéu, Mila de la Roca. No momento da captura carregava escravos procedentes de Moçambique. STUDER, Elena F. S. La trata de negros en el Río de la Plata durante el siglo XVIII, op. cit. Anexo, gráfico: Buques negreros llegados al Rio de la Plata desde 1742 hasta 1806.

${ }^{40}$ LUCENA SALMORAL, Manuel. Los nódigos negros de la América Española. Madri: Unesco/ Universidad de Alcalá, 1996.

${ }^{41}$ LUCENA SALMORAL, Manuel. Los códigos negros de la América española, op. cit.; MARQUESE, Rafael de Bivar. Feitores do corpo, missionários da mente: senhores, letrados e o controle dos escravos nas Américas (1660-1860). São Paulo: Companhia das Letras, 2004.
} 
de Pobres descreve, entre suas funçôes, a da defesa dos escravos e de todo sujeito que, não podendo ou não devendo, se pretenda escravizar.

Quais eram as funçôes do Defensor de Pobres? ${ }^{\text {42 }}$

Afirma Rebagliati que a figura do Defensor de Pobres foi peça central no dispositivo judicial do cabildo do período colonial tardio. Este cargo era exercido gratuitamente por um de seus regedores pelo termo de um ano, período no qual se ocupava da defesa de escravos, indígenas, mulatos e mulheres pobres. ${ }^{43}$ Apesar de a figura do Defensor de Pobres datar de 1722, suas funçóes de defensoria de pobres e menores (desvalidos) se delimitam a partir das ordenaçôes capitulares, que no caso de Buenos Aires são de 1695, e seu desenvolvimento e sistematização é resultado da prática cotidiana, pois as ordenaçôes só falam de que esses menores devem contar com alguém que faça as vezes de pai. ${ }^{44}$

Tomás Antonio Romero, como defensor de escravos, diz, em 1799, zelar pela educação, trato, alimentação e até liberdade dos escravos, para representar-lhes contra seus senhores quando necessário. Diz defender a liberdade quando, por razóes naturais, os "negros" tivessem nascido livres de ventres livres, bem como quando a gozam por ter sido deixada em testamento ou por qualquer outro instrumento legal estabelecido por algum reino ou república. Nesta última circunstância podiam ser enquadrados os mais de 500 negros capturados com o navio português a Rainha dos Anjos. A "generosa república francesa", como é chamada por Tomás Antonio Romero, havia abolido a escravidão em seus domínios e disso, dizia o regedor, temos documentos suficientes. Todos os domínios franceses têm abolido a escravidão, excetuando a ilha de Maurício, da qual já haviam chegado alguns escravos a Buenos Aires, segundo o dizer dele. ${ }^{45}$ Comenta também as notícias, que seriam de público conhecimento, de outros corsários franceses que capturando presa portuguesa e inglesa com carregamento de escravos os teriam libertado. Argumenta que desde o mesmo momento em que La Republicaine se apoderou da corveta portuguesa na costa brasileira, aqueles negros começaram a gozar da liberdade, da mesma liberdade com que tinham vindo ao mundo. ${ }^{46}$

Para Romero o comandante Le Bozec não tinha nenhum direito sobre os negros apresados no navio português. O fato de ter apresado os "negros" em corso não lhe dava direi-

\footnotetext{
${ }^{42}$ ZAPATA DE BARRY, Ana María. El Protector de Naturales y el Defensor General de Pobres en la estructura jurídica colonial de la América Hispana. Revista Ministerio Público de la Defensa, ano 1, n. 3, p. 119-123, nov. 2007.

43 REBAGLIATI, Lucas Esteban. Caridad y control social en el Buenos Aires virreinal: el caso de los Defensores de pobres (1776-1809). SEGUNDAS JORNADAS NACIONALES DE HISTORIA SOCIAL La Falda, Córdoba, 2009.

${ }^{44}$ PUGLIESE, María Rosa. Apuntamientos sobre la aplicación del derecho indiano local en el Rio de la Plata. Una creación jurídica empírica. Revista de Historia del Derecho, n. 33, p. 219-295, 2005.

${ }_{45}$ Trata-se dos 20 escravos que trouxera consigo a família Perichón y Vandeul, emigrada da Ilha Mauricio a Buenos Aires um ano antes. "Llegada a Montevideo de fragata francesa María Eugenia", 1797, Estado 81, n. 12, Archivo General de Indias.

${ }^{46}$ Arribo a Montevideo de Fragatas corsarias, 1799. Estado, Buenos Aires, 84, n. 1, Archivo General de Indias.
} 
tos, nem o convertia em senhor deles, já que era contrário às leis francesas. Por mais que o cidadão Le Bozec se encontrasse num território em que estava permitido o comércio de escravos, esta permissão era para os vassalos da Espanha e outras nações cujas leis admitiam o comércio de escravos. Os dias de janeiro de 1799 se passavam e o Defensor de Pobres fazia com que seus escritos atravessassem o rio uma e outra vez de Buenos Aires a Montevidéu e de Montevidéu a Buenos Aires. Sempre insistindo no mesmo argumento, embora reconhecesse que podiam ser levantados outros. Lembrava que a Recopilação de Leis de Índias e as leis municipais e os tratados entre Espanha e Portugal não permitiam a alienação da presa. Também salientou que em 1797 houve um antecedente em que um corsário francês, o cidadão Lamberty, tinha pedido licença para vender três navios portugueses e lhe foi negada pelo fiscal do crime. Mas, apesar de mencionar este antecedente, ele mesmo diz que não utilizaria desse argumento, nem buscaria inibir a venda dos navios, somente se opunha à venda dos escravos. Que sejam declarados livres de toda escravidão!, dizia uma e outra vez.

Grande humanista seria Tomás Antonio Romero se não fosse, ademais de Defensor de Pobres, traficante de escravos. Ele mesmo tinha perdido propriedade escrava em mãos dos corsários franceses. Parece que o pleito dele era esse. Não seria arriscado pensar que buscava com este caso exemplar inibir a interferência dos corsários franceses no tráfico de escravos. Solicitava a distribuição gratuita de mais de 500 "negros" entre os lavradores das redondezas de Montevidéu e Buenos Aires. Diz: "el comandante Le Bozec, ni otro corsario de su nación está facultado para aquel genero de corso, es decir para la presa de esclavos por la inutilidad de la misma." ${ }^{77}$ Segundo Silva, era Romero um dos principais escravistas que mantinha e fomentava as relaçóes comerciais com o Brasil, "Seja suficiente dizer que, entre 1793 e 1795, introduziu 1.614 escravos das colônias portuguesas, 354 transportados em barcos espanhóis e 1.260 em portugueses" ${ }^{48}$ Fica mais ou menos claro que quem fala é o traficante, mais que o Defensor. Sei que é difícil avaliar quais são as verdadeiras intenções de Romero. Ele fez um trabalho de defesa cuidadoso, recorrendo ao direito internacional e de gentes, privilegiando a liberdade, como indicavam as Sete Partidas. Romero entendia que a embarcação La Republicaine era parte da soberania territorial do Estado francês. Mas não somente ela, senão também sua presa, uma vez que estava sob o domínio do capitão Le Bozec. Compreendia que se tratava de uma presa justa já que não buscou restituir o domínio sobre os navios e carregamentos a seus respetivos capitães portugueses. Mas justamente por ser uma presa justa tinha-se produzido a metamorfose de seu carregamento humano de escravos em livres. Como diz Lauren Benton, o mundo marítimo era mais do que uma carreira de obstáculos para os comerciantes, "era parte integral de um amplo campo político e jurídico”. Neste sentido, afirma, os corsários devem ser entendidos no contexto dos intentos por reconfigurar

\footnotetext{
${ }^{47}$ Idem.

${ }^{48}$ Baste decir que, entre 1793 y 1795, introdujo 1.614 piezas desde las colonias portuguesas, 354 transportadas en barcos españoles y 1.260 en portugueses. SILVA, Hernán Asdrúbal. Bases para el establecimiento de vínculos comerciales entre el Río de la Plata y el Brasil a fines de la etapa colonial, op. cit., p. 477.
} 
soberanias. ${ }^{49}$ No caso analisado o reconhecimento da soberania francesa implicava alguns desdobramentos, ou pelo menos estes estavam sujeitos a interpretaçóes.

O fiscal em matéria criminal achava que o regedor, Defensor de Pobres, Tomás Antonio Romero, não devia pedir vistas do processo que estava correndo, acreditava que a matéria era estranha à alçada do Defensor de Pobres. A Junta da Marinha estava analisando a legitimidade da presa do barco português. A respeito da situaçấo dos negros que tinham chegado no Rainha dos Anjos, o tenente Aguacil Mayor e o escrivão receberam ordem do governador para ver como estavam e se houvera perdas, como denunciava Romero dizendo que o capitáo estava utilizando subterfúgios para vender os negros como escravos. A última notícia que ele tinha era de que o capitão os estava dando de presente, recebendo o dinheiro de forma escondida. Os escravizados tinham sido alocados em dois pontos distantes a uma légua e meia e três quartos de légua, respectivamente, de Montevidéu. O primeiro ponto, uma charqueada, e o segundo, um local que era chamado de "caserío dos negros". ${ }^{50}$ No primeiro havia 43 negros e no segundo 375. Segundo o registro dos encarregados desses postos tinham morto 14 no primeiro lugar e 16 no segundo. Faltavam 97 negros dos 545 que tinham ingressado na Rainha dos Anjos. As suspeitas e os boatos recolhidos pelo Defensor pareciam confirmar-se.

Parece que o Defensor de Pobres estava com pressa para que a carga do Rainha dos Anjos fosse libertada, passando por alto aquilo que se constituía em questáo principal, isto é, era se a presa era legítima ou não. Nesse sentido a sua proposta fundava, como ele mesmo chegou a enunciar, precedentes que demonstrassem que a apreensão de barcos negreiros por parte de corsários franceses era inútil e improdutiva porque eles não estavam habilitados para esse comércio. Aqui desnudava uma das questôes fundamentais do corso, que, mais que ocasionar perdas aos inimigos, buscava a realização da riqueza. O fiscal do crime insistiu em que devia definir-se antes de mais nada se a presa era legítima ou não. Se a presa não era legítima, entáo o barco e as mercadorias voltavam a seus donos anteriores, neste caso, retornaria para o armador e o capitão portugueses e, seguindo os argumentos do Defensor, estes sim tinham "legitimidade" para comerciar escravos, o que tampouco interessava ao Defensor/traficante.

Nos anos imediatamente anteriores, Pedro Duval, Manuel Aguirre e Tomás Antonio Romero tinham comprado embarcaçóes portuguesas em portos brasileiros destinadas ao comércio de escravos procedentes da África. ${ }^{51}$ Em meio ao "affaire" La Republicaine e Le

\footnotetext{
${ }^{49}$ BENTON, Lauren, Una soberanía extraña: la provincia Oriental en el Mundo Atlântico. 20/10 Historia, op. cit., s/p.

${ }^{50}$ O "caserío de los negros" foi construído em 1788 por ordem do Cabildo de Montevidéu pela Companhia Real de Filipinas para que os escravos ficassem em quarentena. Ver: CHAGAS, Karla; STALLA, Natalia; BORUCKI, Alex. Caserio de los negros. In: Sitios de Memória y culturas vivas de los afrodescendentes. Argentina, Paraguay y Uruguay. La ruta del Esclavo, Unesco, 2012, p. 116-125.

${ }^{51}$ Pedro Duval para que se declare como nacional el barco nombrado "El Feliz Gobierno", que mandó comprar em Geneiro para el tráfico de negros. Además pide se le libere del pago de derechos de alcabalas, 1795; Al Administrador de la Real Aduana de Buenos Aires para que se cobren los derechos correspondientes a la compra que realizó Dn Pedro Duval de la Zumaca Ntra Sra de la Concepción, con una carga de 166 piezas
} 
Grand Bonaparte, os maiores traficantes de escravos do Prata receberam seus carregamentos de escravos procedentes do Brasil. ${ }^{52} \mathrm{O}$ movimento do porto de Montevidéu assim o evidencia. Para este grupo, esta era a rota principal, e este o parceiro comercial de preferência.

Nos anos seguintes o embaixador da França em Madri tentou mediar a relação entre o armador de La Republicaine e as autoridades marítimas em Montevidéu. Da mesma forma que o faziam os comerciantes das Américas cada vez que queriam solicitar autorização para introduzir escravos, o embaixador citou a Real Cédula de 24 de novembro de 1791, relativa à introdução de negros. Com isto argumentava que a introdução de escravos via corso era análoga a uma introdução outra qualquer. Em 1805 as autoridades francesas perguntavam: Onde estavam os 573 escravos provenientes das duas naves portuguesas Rainha dos Anjos e Bela Flor? Se tiverem sido confiados aos habitantes de Montevidéu, a quem?

A representação francesa insistiu e conseguiu que a Espanha emitisse passaporte para que um representante do armador viajasse a Montevidéu para reaver as presas. Encontrou parte delas. A metade dos escravos, segundo este representante, estava morta ou "descaminhada" e o apoderado de Le Bozec, Manuel Vásquez, tinha mal vendido o produto do corso..$^{53} \mathrm{~A}$ cada reclamação dos corsários e seus representantes o fiscal respondeu que a diferença de "política" entre a primeira e a segunda arribada se deveu a que na primeira Le Bozec e Carbonell se apresentaram como oficiais da armada francesa e não como corsários, já que as Leis de Índias não permitiam o ingresso de navios estrangeiro.

\section{Conclusão}

O ciclo corsário das guerras napoleônicas ainda se estendeu até (con)fundir-se com o ciclo das independências. Mas o da peculiar conjuntura em que operaram La Republicaine e Le Grande Bonaparte no período em que a França tinha abolido a escravidão e o tráfico de escravos chegou a seu fim em 1802. A guerra pelo domínio dos mares, a reconfiguraçáo e reconhecimentos de soberanias e pelas riquezas americanas ainda continuou. Nos anos seguintes alguns outros corsários franceses e espanhóis (é de destacar, além do já mencionado caso de Hypolito Mordielle, o de El Dromedário, corsário espanhol que apresou vários navios ingleses nos anos de 1804 e 1805) utilizaram aquele cenário dos mares do Sul para

de esclavos. 1796; Solicitud hecha a nombre de Dn Tomas Antonio Romero para efectivizar la compra del Bergantín Portugués "La Madre de los Hombres y San Fco. de Sales" cargado con 137 negros y anclado en Montevideo. 1796

${ }^{52}$ Por exemplo: Sobre la arribada a este puerto de la Fragata "San Fco. De Paula" procedente del Brasil, con cargamento de frutos y 29 negros, a nombre de Manuel Aguirre, 1797-1798.

${ }^{53} \mathrm{O}$ passaporte foi solicitado pelos armadores: Roussilhe, Morainville e Jean Baptiste Rousilhe, os quais encontramos em 1817 pleiteando outra presa realizada em 1797 pelo navio Le Satanique, que então tinha sido armado pela Casa Comercial Pierre Godefroy de Dunkerque, mas da qual eles eram liquidadores. PISTOYE, Alphonse de; DUVERDY, Denis Charles; VALIN, R. J. Traité des prises maritimes. V. 2, Paris: Durand, 1855. 
realizar suas presas. A batalha de Trafalgar definiu para que lado se inclinaria a balança, embora não fosse o ponto final do conflito entre Espanha e Inglaterra, que na América ainda teria seu desfecho final nas guerras de independência. ${ }^{54}$

As açôes dos capitães Le Bozec e Carbonell revelam um conjunto de relaçôes no interior do espaço platino. As açóes dos dois corsários evidenciaram o enfrentamento entre os interesses dos comerciantes vinculados a Cádiz e os vinculados ao Brasil.

O comércio com neutrais, que foi o que permitiu manter as comunicaçôes e o comércio entre América e Espanha, aprovado por Real Ordem de 1797, foi aproveitado principalmente pelos norte-americanos; ${ }^{55}$ embora fossem mais presentes na regiáo do Caribe e o golfo de México, assumem no Rio da Prata um papel importante junto aos já predominantes luso-brasileiros. ${ }^{56}$

Da mesma forma que em Veracruz, onde Marina Alfonso Mola registra que os comerciantes vinculados ao Consulado de Comércio eram desfavoráveis ao arribo de navios norte-americanos e ao comércio direto com Cuba, os integrantes do Consulado de Comércio de Buenos Aires também se inclinaram pela defesa dos interesses gaditanos, vinculados a seus negócios, contrariando muitas vezes as políticas econômicas propostas por Madri. Ainda assim, o Consulado de Comércio não era unânime e ao seu interior cresciam as rivalidades. $\mathrm{O}$ comércio de escravos, favorecido pela Espanha nas últimas décadas do século XVIII, era do agrado de um grupo de comerciantes locais, os traficantes, mas náo da maioria do grêmio dos comerciantes. ${ }^{57}$ É de destacar que em 1799 a Espanha aboliu a Real Ordem sobre o comércio com neutrais, por causa da pressáo dos comerciantes americanos vinculados a Sevilha.

O relativo insucesso dos corsários Le Bozec e Carbonell no Rio da Prata se deveu a essa peculiar conjuntura em que os traficantes de escravos platinos estavam muito interessados em ampliar suas operaçôes, tendo como sócios os experientes luso-brasileiros. É difícil avaliar o êxito ou fracasso da estratégia de Tomás Antonio Romero, que evidenciava, como o romance de Alejo Carpentier, o paradoxo de que a expansão da Revolução Francesa e, portanto, do abolicionismo francês (1794-1802), implicasse em alguns lugares da América a ampliação da escravidão. ${ }^{58}$

\footnotetext{
${ }^{54}$ GUIMERÁ RAVINA, Agustín; BUTRÓN, Gonzalo. Trafalgar y el mundo atlántico. Madri: Marcial Pons, 2004.

${ }^{55}$ ALFONSO MOLA, Marina. El comercio marítimo de Cádiz (1797-1805). In: GUIMERÁ RAVINA, Agustín; BUTRÓN, Gonzalo. Trafalgar y el mundo atlántico. Madri: Marcial Pons, 2004, p. 265-268.

${ }^{56}$ ASDRUBAL, Hernan. El arribo de los primeros navíos neutrales norteamericanos al Rio de la Plata y su incidencia en el sistema comercial. Revista Españolaa de Estudios Norteamericanos, n. 5, 1992.

${ }^{57}$ KRASELSKY, Javier Gerardo. Las estratégias de los actores en el Rio de la Plata: las juntas y el consulado de comercio de Buenos Aires a fines del Antiguo Regimen. 1748-1809. Tese (doutorado) — Universidad Nacional de La Plata, 2011, p. 189-190.

${ }^{58}$ SAES, Laurent Azevedo Marques de. A primeira abolição francesa da escravidão (4 de fevereiro de 1794) e o problema dos regimes de trabalho. Saeculum, Revista de História, João Pessoa, n. 29, p. 125-143, jul./dez. 2013.
} 
El Capitán sacó de su despacho un pliego de instrucciones escritas de puño y letra de Víctor Hugues: "Francia, en virtud de sus principios democráticos, no puede ejercer la trata. Pero los capitanes de navíos corsarios, están autorizados, si lo estiman conveniente o necesario, a vender en puertos holandeses los esclavos que hayan sido tomados a los ingleses, españoles y otros enemigos de la República.” “Pero esto es infame!” — exclamó Esteban — “¡Y hemos abolido la trata para servir de negreros entre otras naciones??

Romero pode ter sido só uma peça, mas fundamental, na máquina da escravidão platina. Sua interferência no processo de legitimação das presas corsárias criou grande incômodo e, embora sua ingerência não fosse adequada do ponto de vista administrativo, evidenciou a fina linha que dividia legalidade e legitimidade. Seu argumento fundamental, baseado no direito de gentes, de que a escravidão é injusta do ponto de vista do humanismo, mas legítima porque legal, mostrava até que ponto a classe de traficantes era capaz de chegar para manter e defender seus interesses, além de evidenciar um profundo envolvimento com as teorias sobre soberania e direito de gentes.

Os anos de maior tráfico no Rio da Prata coincidiram em boa parte com o reestabelecimento da escravidão colonial francesa. Para então os corsários franceses tinham conseguido "fazer negócios" com os traficantes portenhos e montevideanos. ${ }^{60}$

\section{Fontes documentais}

Al Administrador de la Real Aduana de Buenos Aires para que se cobren los derechos correspondientes a la compra que realizó Dn Pedro Duval de la Zumaca Ntra Sra de la Concepción, con una carga de 166 piezas de esclavos. 1796. Aduana de Buenos Aires. Correspondencia (1779-1796) Sala IX 10-4-3 Archivo General de la Nación Argentina.

Capitán General de Caracas sobre corsarios franceses, 1798. Estado, Caracas, 67, n. 56, Archivo General de Indias.

Consulado de Buenos Aires, 1800-1807, sala IX-4-8-2. Archivo General de la Nación Argentina. Consulado de Buenos Aires, 1771-1793, sala IX, 4-7-5. Archivo General de la Nación Argentina. Chart of the Marquesas, by Captain James Wilson in the ship Duff, 1797, Filipinas, Archivo General de Indias.

Divisão Colonia, Montevideo, 1799. Sala IX-2-9-4. Archivo General de la Nación Argentina. Excesos cometidos por la corbeta El Gran Bonaparte, 1798. Estado, Buenos Aires, 80, n. 59, Archivo General de Indias.

\footnotetext{
${ }^{59}$ CARPENTIER, Alejo. El siglo de las luces. Barcelona: Club Bruguera, 1980.

${ }^{60}$ GRANDIN, Greg. O império da necessidade. Escravatura, liberdade e ilusão no Novo Mundo, op. cit.
} 
Expediente sobre remitir los frutos del país al Brasil para transbordarlos al comboy portugués y dirigirlos a Lisboa con destino a los puertos de la metropolis. Consulado de Buenos Aires, 1771-1793, Archivo General de la Nación Argentina.

GREGORY, William. Manifestación visible de la divina providencia. Diario de un misionero cautivo 1798-1799. Estudio preliminar de José Maria Mariluz Urquijo. Buenos Aires: Congreso de la Nación/Academia Nacional de la Historia, 1996.

Llegada a Montevideo de fragata francesa María Eugenia, 1797. Estado, Buenos Aires, 81, n. 12, Archivo General de Indias.

Pedro Duval para que se declare como nacional el barco nombrado "El Feliz Gobierno", que mandó comprar em Geneiro para el tráfico de negros. Además pide se le libere del pago de derechos de alcabalas, 1795, Comerciales, Sala IX 31-1-2, Archivo General de la Nación Argentina.

PISTOYE, Alphonse de; DUVERDY, Denis Charles; VALIN, R. J. Traité des prises maritimes. V. 2, Paris: Durand, 1855.

Real Cédula de S. M. y Señores del Consejo en que se manda observar y guardar el tratado de Alianza ofensiva y defensiva ajustado entre su Real Persona y la República Francesa. 1796. Por Bartolomé Muñoz Torres, Espańa, Imprenta Real, 1796.

Real Cédula de S. M. y señores del Consejo, en que se prohíbe la venta de los Tratados de la Paz ajustada con la Francia, que no se hayan impreso en la Real Imprenta de Madrid, y también su reimpresión y la de qualesquiera otros papeles ú obras que se manden imprimir por S.M., á no preceder su soberano consentimiento. Segovia, Imprenta Espinosa, 1796.

Real Cédula de su Magestad concediendo libertad para el comercio de negros, con las islas de Cuba, Santo Domingo, Puerto Rico, y Provincia de Caracas, á Españoles y Extranjeros, baxo las reglas que se expresan. Madrid en la imprenta de la Viuda de Ibarra.

Recurso de Don Tomás Antonio Romero sobre permiso de introducción de negros de los brasiles a estos dominios. 1786. Tribunales, Legajo 234, exp. 26, Sala IX 39-1-3, Archivo General de la Nación Argentina

Sobre preparativos sospechosos de portugueses e ingleses, 1797. Estado, Buenos Aires, 81, n. 14. Archivo General de Indias.

Solicitud hecha a nombre de Dn Tomás Antonio Romero para efectivizar la compra del Bergantín Portugués "La Madre de los Hombres y San Fco. de Sales" cargado con 137 negros y anclado en Montevideo. 1796. Hacienda. Sala IX 9-10-7 (Diciembre de 1795), n. 1. Archivo General da la Nación Argentina.

Tratado preliminar de paz e limites na América Meridional relativo aos estados que nella possuem as coroas de Portugal e de Hespanha. Lisboa, Regia Oficina Typográfica, 1777.

Virrey de Buenos Aires sobre salida de una presa inglesa, 1797. Estado, Buenos Aires, 80, n. 69, Archivo General de Indias. 
Virrey Interino de Buenos Aires sobre envío de navíos, 1797. Estado, Buenos Aires, 81, n. 13, Archivo General de Indias.

\section{Referências bibliográficas}

ALFONSO MOLA, Marina. "El comercio marítimo de Cádiz (1797-1805)”, In: GUIMERÁ RAVINA, Agustín; BUTRÓN, Gonzalo. Trafalgar y el mundo atlántico, Madri: Marciel Pons, 2004, p. 265-268.

ASDRUBAL, Hernan. El arribo de los primeros navíos neutrales norteamericanos al Rio de la Plata y su incidencia en el sistema comercial. Revista Española de Estudios Norteamericanos, n. 5,1992 .

AZCARRAGA Y DE BUSTAMANTE, José Luis de. El corso maritimo, concepto, justificación e historia. Madri: Consejo Superior de investigaciones científicas, 1950.

BENTANCUR, Arturo Ariel. El Puerto colonial de Montevideo. Tomo 1. Montevidéu: Universidad de la República, 1997.

BENTON, Lauren. Una soberanía extraña: la provincia Oriental en el Mundo Atlântico. 20/10 Historia. México: GM Ediciones, 2012.

BORUCKI, Alex. The Slave Trade to the Río de la Plata, 1777-1812: Trans-Imperial Networks and Atlantic Warfare. Colonial Latin American Review, v. 20, n. 1, p, 88, abr. 2011.

CARPENTIER, Alejo. El siglo de las luces. Barcelona: Club Bruguera, 1980.

CHAGAS, Karla; STALLA, Natalia; BORUCKI, Alex. Caserio de los negros. In: Sitios de Memoria y culturas vivas de los afrodescendentes. Argentina, Paraguay y Uruguay. La ruta del Esclavo. Unesco, 2012, p. 116-125.

COONNEY, Jerry W. Neutral Vessels and Platine Slavers: Building a Viceregal Merchant Marine. Journal of Latin American Studies, v. 18, n. 1, p. 25-39, 1986.

. Oceanic Commerce and Platine Merchants, 1796-1806: The Challenge of War. The Americas, v. 45, n. 4, p. 509-524, abril 1989.

CRUZ BARNEY, Oscar. El corso maritimo, México: UNAM, 2013, p. 82.

FLORENTINO, Manolo; RIBEIRO, Alexandre Vieira; SILVA, Daniel Domingues da. Aspectos comparativos do tráfico de africanos para o Brasil (séculos XVIII e XIX). AfroÁsia, n. 31, p. 83-126, 2004.

GALLOIS, Napoleon. Corsaires françaises sous la République et l'empire. Le Mans: Julien Lanier et Co. Libraires — Editeurs/Paris: Ledoyen Galerie D’Orleans, 1847, p. 13-14.

GRANDIN, Greg. O império da necessidade. Escravatura, liberdade e ilusão no Novo Mundo. Rio de Janeiro: Rocco, 2014. 
GUIMERÁ RAVINA, Agustín; BUTRÓN, Gonzalo. Trafalgar y el mundo atlántico. Madri: Marciel Pons, 2004.

JOHNSON, Lyman. Los talleres de la Revolución. La Buenos Aires plebeya y el mundo del Atlántico, 1776-1810. Buenos Aires: Prometeo, 2013.

JUMAR, Fernando. Colonia de Sacramento y el complejo portuario rio-platense 17161778. In: SILVA, Hernan (Dir.). Los caminos del Mercosur: Historia económica regional. Etapa Colonial. México: Instituto Panamericano de Geografia e Historia, 2004.

KRASELSKY, Javier Gerardo. Las estratégias de los actores en el Rio de la Plata: las juntas y el consulado de comercio de Buenos Aires a fines del Antiguo Regimen. 1748-1809. Tese (doutorado) - Universidad Nacional de La Plata, 2011, p. 189-190.

LUCENA SALMORAL, Manuel. Los códigos negros de la América española. Madri: Unesco/ Universidad de Alcalá, 1996.

. Piratas, bucaneros, filibusteros y corsarios en América. Madri: Editorial MAPFRE, 1992.

MARQUESE, Rafael de Bivar, Feitores do corpo, missionários da mente: senhores, letrados e o controle dos escravos nas Américas (1660-1860). São Paulo: Companhia das Letras, 2004. MELVILLE, Herman. Bartleby, el escribiente. Benito Cereno. Billy Budd. Madri: Editorial Cátedra, 1993.

MORENO ÁLVAREZ, Leonardo Guillermo. La piratería americana y su incidencia en el Nuevo Reino de Granada, siglos XVI-XVIII: un ensayo bibliográfico. Fronteras de la Historia, n. 12, p. 373-404, 2007.

NAVARRO FLORIA, Pedro. El consulado de Buenos Aires, 1790-1806. Tese (doutorado) Universidad Complutense, Madri, 1992.

ORTEGA, Exequiel Cesar, El complot colonial. Buenos Aires: Ayacucho, 1947.

PALOMBO, Guillermo; IGARZÁBAL CLAUSSE, Luis Miguel de. "El "grande expediente" del pleito de los frutos (1794-1795)", Temas de Historia Argentina y Americana 21 (2013). Disponível em: <http://bibliotecadigital.uca.edu.ar/repositorio/revistas/grande-expedientepleito-frutos.pdf>.

PRADO, Fabrício Prado. A carreira transimperial de don Manuel Cipriano de Melo no Rio da Prata do século XVIII. Topoi, v. 13, n. 25, p.168-184, 2012.

PUGLIESE, María Rosa, Apuntamientos sobre la aplicación del derecho indiano local en el Río de la Plata. Una creación jurídica empírica. Revista de Historia del Derecho, n. 33, p. 219-295, 2005.

REBAGLIATI, Lucas Esteban. Caridad y control social en el Buenos Aires virreinal: el caso de los Defensores de pobres (1776-1809). SEGUNDAS JORNADAS NACIONALES DE HISTORIA SOCIAL, La Falda, Córdoba, 2009. 
. La administración de Justicia en Buenos Aires: del período virreinal a la sanción de la Constitución Nacional (1776-1853). In: Teoría General Procesal 2. Buenos Aires: Ediciones Jurídicas Eduardo Lecca Editor, 2011.

RODRIGEZ, Benjamín. Una justicia no tan lejana: los comerciantes y el tribunal del Consulado de Buenos Aires, entre su fundación y los primeros años independientes. Revista Historia del Derecho, Ciudad Autónoma de Buenos Aires, n. 47, p. 149-170, jan./jun. 2014. RODRIGUEZ TREVIÑO, Julio César. La red del corsario francés Juan Chevalier y sus presas angloamericanas en el Caribe durante las guerras navales (1796-1808). Revista América Latina en la Historia Económica, Instituto Mora, México, ano 22, n. 1, p. 105-149, jan./abril 2015.

ROUVIER, Charles. Histoire des marins français sous la République (de 1789 a 1803). Paris: Arthur Bertrand Éditeur, 1868.

SAES, Laurent Azevedo Marques de. A primeira abolição francesa da escravidão (4 de fevereiro de 1794) e o problema dos regimes de trabalho. Saeculum, Revista de História, João Pessoa, n. 29, p. 125-143, jul./dez. 2013.

SECRETO, Maria Verónica. Brindes, textos e livros proibidos: a conspiração de escravos e franceses na Buenos Aires colonial. Outros Tempos, v. 11, p. 188-207, 2014.

. Sediciosa Buenos Aires: o complot de escravos e franceses no Rio da Prata, 1795. Historia Unisinos, v. 17, p. 146-157, 2013.

SILVA, Hernán Asdrúbal. Bases para el establecimiento de vínculos comerciales entre el Río de la Plata y el Brasil a fines de la etapa colonial. Anuario de Estudios Americanos. Tomo LIV, n. 2, p. 475-488, 1997.

. El arribo de los primeros navíos neutrales norteamericanos al Rio de la Plata y su incidencia en el sistema comercial. Revista Española de Estudios Norteamericanos, Universidad de Alcalá de Henares n. 5, 1992.

. El comércio entre España y el Rio da la Plata (1778-1810). Madri: Banco de España, 1993.

. El corso rioplatense de fines del XVIII y principios del XIX. Una actividad sui generis XVII Coloquio de historia canario-americana. Las Palmas de Gran Canaria: Cabildo de Gran Canaria, 2006, p. 1592.

STUDER, Elena S. F. La trata de negros en el Río de la Plata durante el siglo XVIII. Buenos Aires: Ed. da UBA, 1958.

TEJERINA, Marcela. Luso-brasileños en el Buenos Aires virreinal: trabajo, negocios e intereses en la plaza naviera y comercial. Bahia Blanca: EdiUNS, 2004.

TORRES PUGA, Gabriel. Centinela Mexicano contra francmasones. Un enredo detectivesco del licenciado Boruda en las causas judiciales contra los franceses de 1794. EHN, n. 33, p. 57-94, jul./dez. 2005. 
Territorialidades fluidas: corsários Franceses e tráfico negreiro no Rio da Prata (I796-I799).

VIDALES, Carlos. Corsarios y piratas de la Revolución Francesa en las aguas de la emancipación hispanoamericana. Caravelle, n. 54, p. 247-262, 1990.

ZAPATA DE BARRY, Ana María. El Protector de Naturales y el Defensor General de Pobres en la estructura jurídica colonial de la América Hispana. Revista Ministerio Público de la Defensa, ano 1, n. 3, p. 119-123, nov. 2007. 